2010

\title{
British Politics, the Welfare State, and Tort Liability of Public Authorities
}

Dan Priel

Osgoode Hall Law School of York University, dpriel@osgoode.yorku.ca

Follow this and additional works at: http://digitalcommons.osgoode.yorku.ca/all_papers

Part of the Law Commons

\section{Repository Citation}

Priel, Dan, "British Politics, the Welfare State, and Tort Liability of Public Authorities" (2010). All Papers. Paper 253.

http://digitalcommons.osgoode.yorku.ca/all_papers/253 


\title{
BRitish POLITICS, THE Welfare STATE, AND TORT LiABILITy OF PUblic AUTHORITIES
}

\author{
Danny Priel
}

\begin{abstract}
There has been a notable shift in the scope of negligence liability of public authorities in the Post War period. Notably there was a trend toward restriction of liability in the 1980s. This essay tries to explain why this happened not by focusing on changing legal formulas but by examining the political context of the law in this area. I begin the essay by demonstrating how changes in the attitudes toward the role of the state in Post-War Britain have led to the changes in the law in this area. I then go on to examine the impact of Thatcher's ascent to power. Some commentators have suggested that the restriction in liability that took place during the years of her premiership was the result of the impact of Thatcherite ideology on the courts. I consider why such an ideology might be used to justify restriction of liability on public authorities, but argue that such arguments are quite different from those actually found in court decisions from that period. Though founded on ideas that can be called broadly 'conservative', they do not reflect the distrust of state institutions typical in New Right writings, but are rather based on great respect for them, a view that reflects a different strand of conservatism. I demonstrate this attitude from the cases and offer some explanations for its possible adoption by the courts.
\end{abstract}

Keywords: tort, conservatism, public authorities, negligence, ideology, New Right.

\section{Introduction}

[T] he ideas of economists and political philosophers, both when they are right and when they are wrong, are more powerful than is commonly understood. Indeed the world is ruled by little else. Practical men, who believe themselves to be quite exempt from any intellectual influences, are usually the slaves of some defunct economist. ... I am sure that the power of invested interests is vastly exaggerated compared with the gradual encroachment of ideas. Not, indeed, immediately, but after a certain interval; for in the field of economic and political philosophy there are not many who are influenced by new theories after a certain interval.... But, soon or late, it is ideas, not vested interests, which are dangerous for good or evil. ${ }^{1}$

Keynes's General Theory is now back in fashion, something that may be the ultimate vindication of its famous concluding words. But these words are relevant not only to economists and political philosophers, they are relevant to lawyers as well. For in law, and perhaps especially in the academic study of law,

"Visiting Professor, Osgoode Hall Law School; Assistant Professor, University of Warwick School of Law. I presented this essay in a staff seminar at Warwick and I thank my colleagues for their many interesting and useful comments.

${ }^{1}$ J.M. Keynes, The General Theory of Employment, Interest, and Money (London: Macmillan, 1936) 383-384. 
it is the 'practical men' who examine the law exclusively through the prism of doctrinal rules who fail to see how much the rules they are analysing are subject to the encroachment of ideas. This essay is an attempt to examine this insight in one area, that of negligence liability of public authorities.

Being at the intersection of public and private, liability of public authorities seems particularly apt for such an analysis, but though there is no lack of theoretical work on tort law, this area has remained relatively unexplored. Work in this area that draws on moral philosophy usually considers tort law to be fundamentally a set of rules of individual moral responsibility, which operate in relative autonomy from broader political or social context. ${ }^{2}$ In the case of economic analysis of tort law, the lack of concern for this question is due to the application of a microeconomic model to explain tort liability. In that model tort liability is based on assessing the costs and benefits that accrue from various activities. To be sure, these costs are likely to be different for different actors, but the model does not call for any special treatment of the fact that the state is involved in the activity.

By contrast, doctrinal work usually follows the courts in treating this area as one governed by special rules and thus partly separate from negligence liability in general. But work in this mould usually focuses on careful analysis of the legal rules enunciated in court decisions in an attempt—often against rather long odds - to reconcile them and show how they all fit a certain set of principles. I do not wish to belittle the significance of this work. As some commentators have said, this is an area of law which 'has threatened to descend into chaos' and is in 'continuing search for coherence', ${ }^{3}$ and close examination of the case-law can help distinguish the bad arguments (of which this area seems have more than its fair share) from the good ones. ${ }^{4}$ But there is a limit to what can be achieved by this approach when the impact of broader normative considerations is not brought into the picture. What is missing is an examination of the proper scope of state action and the relationship between the state and the individuals subject to its powers. To put it starkly, one cannot adequately answer the question for what the state may be liable to individuals in tort unless one has some idea on the question what the state owes individuals. And this, plainly, is a political question about which the focus on

${ }^{2}$ This is quite explicit in Arthur Ripstein, 'The Division of Responsibility and the Law of Tort' (2004) 72 Fordham L Rev 1811-44, 1814-1815, 1830; John CP Goldberg \& Benjamin C Zipursky, 'Accidents of the Great Society' (2005) 64 Maryland L Rev 364-408, 368, 391.

${ }^{3}$ MJ Bowman \& SH Bailey, 'Public Authority Negligence Revisited' (2000) 59 CLJ 85-132, 132; Stephen Bailey, 'Public Authority Liability in Negligence: The Continued Search for Coherence' (2006) 26 LS 155-84. The same view is expressed in the Law Commission's Administrative Redress: Public Bodies and the Citizen (Consultation Paper No. 187, 2008) \$3.148.

${ }^{4}$ Among many others see Richard O'Dair, 'Murphy v Brentwood District Council: A House with Firm Foundations?' (1991) 54 MLR 561-70; Marianne Giles \& Erika Szyszczak, 'Negligence and Defective Buildings: Demolishing the Foundations of Anns' (1991) 11 LS 85-102; BS Markesinis \& Simon Deakin, 'The Random Element of their Lordships' Infallible Judgment: An Economic and Comparative Analysis of the Tort of Negligence from Anns to Murphy' (1992) 55 MLR 619-46. 
doctrine is largely unhelpful, if not positively harmful for tending to focus attention on certain verbal formulas instead of the underlying normative questions.

Examining these matters is significant not only for answering the normative questions on what the scope of tort liability on public authorities should be. It can also help us understand major trends and shifts in the law, and can thus help in understanding the state of the law exactly by highlighting the bigger picture that more fine-grained doctrinal analysis tends to miss. For example, exclusive focus on legal rules can offer only limited help in explaining why English courts have adopted a very restrictive attitude to the imposition of tort liability on public bodies, one for which it is difficult to find comparison in other jurisdictions. ${ }^{5}$ Another such question, and the one which will be the subject of this essay, is what can explain the marked change in attitude toward negligence liability of public authorities that took place in the 1980 .

At a doctrinal level one can begin with the recent history of the courts' attitude toward negligence liability in general and trace the changes with regard to public authorities to the changes in the 'tests' for finding a duty of care. In the familiar story it was Anns v Merton London Borough Council, ${ }^{6}$ coincidentally or not a government liability case, that ushered in the 'two-stage test', which was rejected thirteen years later in favour of the seemingly more restrictive 'three-stage test' of Caparo. ${ }^{7}$ It is thus tempting to explain the change in the area of liability of public authorities as part of a more general shift in the scope of negligence liability. But this account does not really answer our puzzle: for the change in the 'test', and prior to it the sense that such a change is needed, must have been based on something not found in the tests themselves. When the House of Lords overruled Anns this was explained by the fact that the latter decision 'did not proceed upon any basis of established principle, but introduced a new species of liability'. ${ }^{8}$ This was said despite the fact that earlier cases, in particular Dorset Yacht (still considered good law today), adopted a very similar formulation to the one supposedly created out of whole cloth in Anns. ${ }^{9}$ To the extent that Anns was a development that went somewhat beyond Dorset Yacht, this by itself is a commonplace in the history of the common law, and of which twentieth century tort law provides numerous examples.

In fact, even at the doctrinal level the change in test is not particularly illuminating, especially if we bear in mind that the law lords themselves have

${ }^{5}$ See Basil Markesinis et al., Tortious Liability of Statutory Bodies: A Comparative and Economic Analysis of Five English Cases (Oxford: Hart, 1999).

${ }^{6}[1978]$ AC 728 (HL).

7 Caparo Industries Plc v Dickman [1990] 2 AC 605 (HL).

${ }_{8}^{8}$ Murphy v Brentwood District Council [1991] 1 AC 398, 471 (HL) (Lord Keith).

${ }^{9}$ See Dorset Yacht $v$ Home Office [1970] AC 1004, 1027 (HL); McGhee v National Coal Board [1972] 1 WLR 1, 6 (HL); cf Cooper v Hobart [2000] SCC 79, [2001] 3 SCR 537 at [27] ('Anns did not purport to depart from the negligence test of Donoghue $v$ Stevenson but merely sought to elucidate it by explicitly recognizing its policy component.). 
frequently warned against paying too much attention to the verbal tests that govern the question of duty of care. ${ }^{10}$ After all, the tests for duty of care in both Anns and Caparo are extremely vague, and it is not too difficult to reach postCaparo outcomes using the Anns test, and vice versa: on the one hand, the House of Lords began narrowing liability for public authorities before the Anns test was officially overruled in $1990 ;{ }^{11}$ on the other, there are a few decisions from recent years that seem to have adopted a more expansive approach to duty of care in a manner more reminiscent of the spirit of Anns than to that of Caparo.

Thus, even though the decision in Caparo was presented as returning the law to its correct course after the ill-advised and unfounded aberration of Anns, Basil Markesinis and his colleagues are, I think, closer to the mark when they say that Caparo and subsequent cases that followed it can equally be called the work of activist judges who departed from earlier principles. ${ }^{12}$ We let ourselves off too easily by saying that the earlier case was 'wrongly decided', that it should be 'confined to its facts'. House of Lords decisions are not the result of some unconsidered extempore, and in the case of Anns one that was made unanimously. The same is true in the other direction. To the courts and many contemporary commentators Dorset Yacht and Anns seemed natural and justified extensions of Donoghue $v$ Stevenson, ${ }^{13}$ but to say that the courts in those cases simply recognised a broad general principle that had not been fully articulated in earlier cases is equally unhelpful. Such conclusions are never required by the earlier decisions, so something else outside the cases must have been at work. The question is what it was.

Before getting to this question, we must, however, attend to the question how we are to find out. One approach, associated in the UK particularly with the work of John Griffith, looks for an answer to these sorts of questions in the judges' personal background. Griffith has pointed out that the vast majority of judges in the Court of Appeal and House of Lords come from a particularly narrow background, have similar education and professional experience, are white, male, and are appointed at an age that tends to lead them to a conservative political and social outlook. ${ }^{14}$ Griffith examined various areas of

${ }^{10}$ See, e.g., Custom and Excise Commissioners v Barclays Bank plc [2006] UKHL 28, [2007] 1 AC 181 at [35] (Lord Hoffmann); Caparo Industries Plc v Dickman [1990] 2 AC 605, 633 (Lord Oliver).

${ }^{11}$ See Governors of the Peabody Donation Fund v Sir Lindsay Parkinson Co Ltd [1985] AC 210 (HL); see also Yuen Kun Yeu v A.G. (Hong Kong) [1988] AC 175 (PC). Similarly, the Canadian Supreme Court continues to adhere to Anns, even after its rejection in its country of origin; nonetheless, it recently moved closer to the post-Caparo English approach. See Cooper at [28], [37]-[39].

${ }^{12}$ Simon Deakin et al., Markesinis \& Deakin's Tort Law (Oxford: Oxford University Press, 6th ed., 2008) $414 \mathrm{n} 102$.

${ }^{13}$ [1932] AC 562 (HL). See note 9 above.

${ }^{14}$ See JAG Griffith, The Politics of the Judiciary (London: Fontana, 5th ed., 1997) 18-22, passim. Recent statistics reveal similar biographical patterns. See Sutton Trust Briefing Note: The 
law and argued that in these areas the judgments display a clear conservative bias, which he explained by the judges' background. The connection between the two was provided by the broadly Marxist perspective Griffith adopted, one according to which the judges' class interests inevitably determine their political, and hence legal, consciousness. Although within this theoretical framework such a link is close to being treated as conceptual, those who do not adopt this framework are unlikely to be convinced by the link Griffith drew between the judges' background and their decisions. ${ }^{15}$ Even someone sympathetic to the idea that the judges inadvertently promote in their judgments certain values or interests may find the almost exclusive focus on the judges' class (as reflected in their parents' occupation and their educational background) too simplistic or reductive.

In the United States Griffith's approach has been studied in much greater depth and sophistication, relying on statistical analysis of vast datasets resulting in what has been described as an 'oppressively comprehensive' examination of 'every aspect of the [US] Supreme Court'. ${ }^{16}$ By contrast in the UK such studies are almost unheard of. ${ }^{17}$ Lacking the data for such an empirical analysis, I still wish to examine the development of the effect of changing political atmosphere on the law developed by judges. The underlying assumption necessary for making such a claim is rather weak: it is, quite simply, that judges are human. This seemingly trivial assumption means that they are likely to be subject to the very same psychological mechanisms that research has shown have affect all humans: cognitive biases, framing effects, and perhaps particularly relevant in this context, cultural worldview. ${ }^{18}$ After all, even the most original thinkers are, in some ways, a reflection of their age; and judges are rarely original thinkers.

For the sake of examining the hypothesis that the law on the negligence liability of public authorities has been influenced by changing political attitudes, I rely on the traditional method of examining the central cases in the field

Educational Backgrounds of the UK's Top Solicitors, Barristers and Judges, available at http://www.suttontrust.com/reports/Comparison_educational_backgrounds.pdf.

${ }^{15}$ It is indeed no surprise that Griffith's work has been severely criticised along these very lines. See Kenneth Minogue, 'The Biases of the Bench', Times Literary Supplement (6 Jan. 1978) 11; Simon Lee, Judging Judges (London: Faber, 1988) 33-39. 2010).

${ }^{16}$ Adam Liptak, 'In a Polarized Court, Getting the Last Word' New York Times (8 March

${ }^{17}$ There are only two works I am familiar with, both written by the same person, that attempt a similar examination of House of Lords decisions. See David Robertson, 'Judicial Ideology in the House of Lords: A Jurimetric Analysis' (1982) 12 Brit J Pol Sci 1-25; David Robertson, Judicial Discretion in the House of Lords (Oxford: Clarendon Press, 1998) ch. 2.

${ }^{18}$ Perhaps not surprisingly, judges are usually much more forthcoming in admitting such influences than the doctrinal scholars who analyse their work without any hint that politics or human psychology has had an impact on the law. For some examples see Viscount Radcliffe, 'Law and Order' in Not in Feather Beds: Some Collected Papers (London: Hamish Hamilton, 1968) 211, 212-214; Patrick Devlin, 'Judges, Government, and Politics' (1978) 41 MLR 501-11, 509; Lord Mustill, 'What Do Judges Do?' (1996) 7 Juridisk Tidskrift 611-24, 619, 622-624; cf McFarlane v Tayside Health Board [2000] 2 AC 59, 82-83 (Lord Steyn). 
(together with some extra-judicial writings of active judges). Though judges often work hard to hide any hint of political influence on their judgments, there is in this area enough evidence from court cases and judges' writings from which we can piece together an account that shows the influence of politics on the development of the law in this field. As I will try to demonstrate, these expressions do not just provide a theoretical background for the law, at times they also help us make more sense of the doctrinal arguments they accompany.

I am, of course, not the first to argue that we can trace changes in private law doctrine to prevailing political ideas. ${ }^{19}$ Surprisingly, however, there has been no detailed discussion of tort liability of public authorities, an area in which the impact of political ideas would seem more immediately relevant. One finds in the literature occasional comments that acknowledge the impact of political ideology, ${ }^{20}$ and there are also brief comparative comments that seek to explain the difference between English and French law in this area to the difference between English (or British) and French attitudes towards the state. ${ }^{21}$ Though a step in the right direction, these throwaway remarks are too general and as such cannot explain some of the puzzles in this area, such as the more restrictive attitude of English courts even in comparison to other Commonwealth courts that share Britain's legal tradition as well as the retrenchment in negligence liability of public authorities that took place during in the $198 \mathrm{os}$.

One explanation, particularly appealing because it might seem relevant to explaining both these puzzles and one that might also explain the more restrictive attitude towards negligence liability more generally, is Thatcher's premiership, or more precisely the influence of the ideas now known as 'Thatcherism'. Perhaps most famous for this claim is Patrick Atiyah, who described the law in the 1970s as reflecting a time 'in which people still believed the role of the state is to take care of people "from the cradle to the grave"', and suggested that some of the restrictions on tort liability against the

${ }^{19}$ For contract law see Duncan Kennedy, 'Form and Substance in Private Law Adjudication' (1976) 89 Harv L Rev 1685; P.S. Atiyah, The Rise and Fall of Freedom of Contract (Oxford: Clarendon, 1977). The best known example of such arguments in tort law has been the claim that various doctrines (like the fellow-servant rule) or the rise of negligence were based on courts' concern with the protection of the interests of business against those of employees and customers at the onset of the industrial revolution. See, most famously, Morton J Horwitz, The Transformation of American Law, I760-1860 (Cambridge: Harvard University Press, 1977) ch. 3. But this thesis has been subjected to considerable criticism. See, among others, Robert L Rabin, 'The Historical Development of the Fault Principle: A Reinterpretation' (1981) 15 Georgia L Rev 925-61; Gary T Schwartz, 'Tort Law and the Economy in Nineteenth Century America: A Reinterpretation' (1981) 9o Yale LJ 1717-75.

${ }^{20}$ For example, Mark Lunney \& Ken Oliphant, Tort Law (Oxford: Oxford University Press, 3rd ed., 2008) 537; cf Jane Stapleton, 'Tort, Insurance, and Ideology' (1995) 58 MLR 820-45, 820; Peter Cane, 'Justice and Justifications for Tort Liability' (1982) 2 OJLS 30-62, 62.

${ }^{21}$ A claim made, for example, in G Monti, 'Osman v. UK-Transforming English Negligence Law into French Administrative Law?' (1999) 48 ICLQ 757-78, 772-773; Duncan Fairgrieve, State Liability in Tort: A Comparative Law Study (Oxford: Oxford University Press, 2002) 265-266 
state that came afterwards reflect the rejection of this view. ${ }^{22}$ Besides Atiyah the influence of Thatcherism has been suggested by other prominent tort scholars as an explanation for various changes in tort liability that took place in this period, although none of these suggestions was developed in much detail. ${ }^{23}$

The argument is appealing because the change in legal doctrine fits the political change, and it seems plausible that when New Right ideas were at their peak, they had impact on the judiciary in ways that reflected themselves, perhaps only semi-consciously, in judicial decisions from the period. However, I will argue below that despite its appeal this suggestion is unsatisfactory for two reasons. First, though the change in the law is correctly attributable to 'conservative judges ${ }^{24}$ and related to the rise to prominence of conservatism in the political scene, it was in fact grounded in ideas quite different from those one would expect to see from judges seeking to implement Thatcherite ideology. Second, as I will try to show the explanation for the shift, though influenced by politics, cannot simply be one in which judges shift their opinions from the left to the right. My contention is, rather, that being human judges were influenced by major political changes in the political discourse they were working in, but that at the same time this influence was filtered through the institutional constraints that English judges see themselves working under, in particular the great importance attached in English (private) law for maintaining a clear separation of law from politics. As I argue, it is this institutional constraint that made certain doctrinal positions plausible against the backdrop of the Post-War consensus on the welfare state difficult to sustain once this consensus was gone.

Here is how I plan to proceed. I begin by describing the shift in public and political attitudes towards public services in the years following World War II. I show that these changes were part of a broader change in attitude towards the role of the state. These changes have led to a more social conception of tort liability, and in particular tort liability of public authorities. I then turn to

${ }^{22}$ See PS Atiyah, The Damages Lottery (Oxford: Hart, 1997) 140-141, 176; $c f$ PS Atiyah, 'Tort Law and the Alternatives: Some Anglo-American Comparisons', [1987] Duke Law Journal 1002$1045,1027-28$. Atiyah proposed a similar explanation for developments in contract law during the same period in PS Atiyah, 'Freedom of Contract and the New Right', in Essays on Contract (Oxford: Clarendon, 1986) 355

${ }^{23}$ See Basil Markesinis \& Jörg Fedtke, 'Authority or Reason? The Economic Consequences of Liability for Breach of Statutory Duty in a Comparative Perspective' (2007) 18 European Business Law Review 5-75, 12-13 (focusing on liability of public authorities); Peter Cane, Tort Law and Economic Interests (Oxford: Clarendon, 2nd ed., 1996) 483 (limitation on the non-contractual protection of economic interests); David Howarth, 'Negligence After Murphy: Time to Re-Think' (1991) 50 CLJ 58-99, 65-66 (Thatcherism offered as a partial explanation of changes in the law in this area); KM Stanton, 'The Decline of Tort Liability for Professional Negligence', (1991) 44 CLP 83,84 . For similar claims about the impact on Thatcherism on public law see Patrick McAuslan \& John F McEldowney, 'Legitimacy and the Constitution: The Dissonance between Theory and Practice' in Patrick McAuslan \& John F McEldowney (eds), Law, Legitimacy and the Constitution: Essays Marking the Centenary of Dicey's Law of the Constitution (London: Sweet \& Maxwell, 1985) 1, 33-35.

${ }^{24}$ As they are described in Markesinis \& Fedtke, above n 23, at 5, 37, 64 . 
outlining the arguments made in support of limiting tort liability of the state. In section II, I first present the arguments of the kind one would hear from someone committed to Thatcherite ideology, and then in section III I demonstrate that the actual arguments found in some of the most important court decisions dealing with the liability of public authorities during Thatcher's premiership reflect an ideology which is very different from, in some sense directly opposed to, Thatcherite ideas. Finally, in section IV I attempt to explain these developments by providing several possible explanations as to why the Thacherite approach did not find favour with the judges.

\section{The Changing State in Post-War Britain}

One finds in British history heroic tales of public servants dedicated to an impossible job, doing it neither for fame nor fortune but out of selfless desire to make life better for those they serve, ${ }^{25}$ alongside tales of corrupt and incompetent mandarins who treat their positions in the public service as sinecure. ${ }^{26}$ Since at any one time one could find enough stories to support both claims, it is tempting to dismiss these different narratives as the result of the ideological bias of the author. But this is not the whole story. Periods of neglect were followed by reforms, which had a positive impact on improving the quality of recruits and their work. ${ }^{27}$ One such period was after World War II. The British civil service, as Peter Hennessey put it, was subjected to reform by that 'well-known expert in public administration, Adolf Hitler'. ${ }^{28}$ The result was that after the reform '[p]ostwar Whitehall was the place to be for the young and the clever with a high personal charge of public duty'. ${ }^{29}$ Similar trends were true of public services more generally: with the disillusion with laissez faire policies for their perceived responsibility for the War the stage was set for a significant change in attitudes regarding the role of the state and a corresponding massive increase in the 'size' of government and the sort of responsibilities for which the public bodies were now called to perform..$^{30}$ At least in part these changes were accepted, even desired, due to another change brought about by World War II. The intense threats it posed were shown to have been a motivating factor in increasing social expenditure by the British

${ }^{25}$ See, e.g., David Roberts, Victorian Origins of the British Welfare State (New Haven: Yale University Press, 1960) 174-176.

${ }^{26}$ See Richard A Chapman \& JR Greenaway, The Dynamics of Administrative Reform (London: Colm Helm, 1980) 37-38.

${ }^{27}$ See Briggs, above n 6, at 85-87, 116-118; Niall Ferguson, Empire: The Rise and Demise of the British World Order and the Lessons for Global Power (New York: Basic Books, 2004) 155 (discussing the 1853 reform to the Indian civil service).

${ }^{28}$ Peter Hennessy, Whitehall (London: Fontana, 1989) 88.

${ }^{29}$ Ibid., at 135 .

30 Roger Middleton, Government versus the Market: The Growth of the Public Sector, Economic Management and British Economic Performance, c. I890-I979 (Cheltenham: Edward Elgar, 1996) §11.3. 
government already during the war years. ${ }^{31}$ Once the threat was gone, the levels of expenditure were difficult to roll back; perhaps one reason why there was no pressure for reducing welfare expenditure was the fact that the war has left its mark on British society and created a sense of solidarity not often seen before between members of the different classes, as well as high levels of trust in the state and its institutions..$^{32}$

All this has had considerable impact on the shape that the British welfare state took in those years, which have led to some fundamental changes in the structure of British society. Importantly, these developments were the work of both Labour and Conservative governments: the so-called 'consensus' years following World War II were the time in which there was relative similarity, at least at the level of policy, on many fundamental issues on the structure of the economy. The leadership of both the Labour and the Conservative parties countenanced a mixed economy, Keynesian economic policies, and was committed to the maintenance, and even expansion, of the welfare state. ${ }^{33}$ Conservative prime minister Harold Macmillan is perhaps most representative of this brand of progressive conservatism. As early as 1938 he published The Middle Way, ${ }^{34}$ a book that drew inspiration from the country whose economic model has come over the years to symbolise benign socialism, Sweden. ${ }^{35}$ When twenty years later he became Prime Minister, he reiterated his continued adherence to its main tenets. ${ }^{36}$ Not only did he not shy away from the idea of planned economy, for him the conservative emphasis on patriotism meant, quite literally, that the state had a parent-like obligations to care for its citizens and make sure that the less fortunate among them are not left behind. ${ }^{37}$

${ }^{31}$ See John Dryzek \& Robert E Goodin, 'Risk-Sharing and Social Justice: The Motivational Foundations of the Post-War Welfare State' (1986) 16 Brit J Pol Sci 1, 11-21.

${ }^{32}$ See TH Marshall, Social Policy in the Twentieth Century (London: Hutchinson, 4th ed., 1975) 82-84; Arthur Marwick, British Society Since 1945 (London: Penguin, 4th ed., 2003) 80; Julian Le Grand, Motivation, Agency and Public Policy: Of Knights, Knaves, Pawns and Queens (Oxford: Oxford University Press, 2003) 4-7. Even literature critical of the solidarity thesis, acknowledges a significant elite minority that was sufficient for establishing the Post-War consensus. See David Kynaston, Austerity Britain: 1945-I95I (London: Bloomsbury, 2007) 39-56, esp. 55-56; Rodney Lowe, 'The Second World War, Consensus, and the Foundation of the Welfare State' (1990) 1 Twentieth Century Brit Hist 152-82, 174-178.

33 Dennis Kavannagh \& Peter Morris, Consensus Politics from Attlee to Major (Oxford: Blackwell, 2nd ed., 1994) 76-77. This is not to deny that on other issues (eg, immigration, relations with Europe) there were still marked differences between the parties.

${ }^{34}$ Harold Macmillan, The Middle Way: A Study of the Problems of Economic and Social Progress in a Free and Democratic Society (London: Macmillan, 1938). See also Lord Kilmuir, 'The Shaftesbury Tradition in Conservative Politics' (1960) 3 J L \& Econ 70. Kilmuir was the Conservative Lord Chancellor in 1954-62.

${ }^{35}$ Macmillan's title and ideas must have been inspired by Marquis W. Childs, Sweden: The Middle Way (New Haven: Yale University Press, 1936). This book is briefly discussed in Macmillan, above $n$ 34, 8o-81.

${ }^{36}$ By contrast, to conservatives of the next generation Macmillan's book could 'hardly count [' as conservative. David Willetts, Modern Conservatism (London: Penguin, 1992) 34

${ }^{37}$ See EHH Green, Ideologies of Conservatism: Conservative Political Ideas in the Twentieth Century (Oxford: Oxford University Press, 2002) ch. 6, esp. 16o-62. 
The consensus years and the expansion of the welfare state were reflected not only in the creation of new public institutions such as the National Health Service and the Industrial Injuries Scheme, but also in a slow but steady expansion of tort liability against the state and employers, an expansion that effectively reoriented tort law towards becoming a mechanism of insurance concerned with the optimal allocation of risks among different groups in society. ${ }^{38}$ The Beveridge Report, published during World War II contained a short discussion of the role of legal liability as one of the means for dealing with industrial accidents and proposed to replace it with an administrative procedure which was part of a more comprehensive welfare scheme. ${ }^{39}$ Shortly afterwards, the defence of common employment was abolished and the defence of contributory negligence was changed from full to partial defence; the Crown Proceedings Act 1947 largely eliminated the immunity of state bodies from private law claims.

The change in political mood, and the statutory developments it begat, have been noticed by academic commentary. Academic lawyers writing at the time started talking about this area of law in terms of what it 'does' (instead of what it 'is'), and increasingly this question has come to be examined within the context of its role within the welfare state. ${ }^{40}$ Towards the end of this period many found tort law wanting and have suggested more or less radical reforms to it, from no-fault liability for accidents to the replacement of the law with social insurance schemes. ${ }^{41}$ Even though these suggested reforms were not adopted, the fact that they have been made is a good indication of what was by then the mainstream academic view as to the appropriate way of thinking about tort law in the modern state.

These changing political and social attitudes, not surprisingly, affected judicial attitudes on tort law as well. We can begin with East Suffolk, ${ }^{42}$ a case in which a majority of the House of Lords rejected a claim against public authorities for being unreasonably slow in fixing a broken wall; this, the claimants contended, resulted in losses from high tides. The majority's opinion was premised on a dichotomy between powers and duties: whenever public authorities are given powers to act, it follows that they cannot be under a duty to act. Not owing such a duty, their failure to act more speedily could give rise to liability. Lord Atkin in dissent rejected the dichotomy: being given a public

${ }^{38}$ See White $v$ White [1950] P 39, 58-59, for a characteristically avant garde statement from Denning J.

${ }^{39}$ Social Insurance and Allied Services (Cmd. No. 6404, 1942) 130-131.

${ }^{4}$ See Glanville Williams, 'The Aims of the Law of Tort' [1951] CLP 137, for an early functionalist study of tort law. For a comparative discussion of the 'massive shift form individual tort liability to some system of private or social insurance' see W Friedmann, Law in a Changing Society (Harmondsworth: Penguin, 2nd ed., 1972) ch. 5. Similar themes are explored in Alfred Denning, Freedom under the Law (London: Stevens and Sons, 1949) 72-75, 77-81.

${ }^{41}$ Terence G Ison, The Forensic Lottery: A Critique of Tort Liability as a System of Personal Injury Compensation (London: Staples, 1967); PS Atiyah, Accidents, Compensation, and the Law (London: Weidenfeld and Nicolson, 1970) 611-614.

${ }^{42}$ East Suffolk River Catchment Board $v$ Kent $[1941]$ AC 74 (HL). 
(statutory) power does not entail that one is not at the same time also under a common law duty to take reasonable care not injure others, a duty that exists 'whether a person is performing a public duty, or merely exercising a power which he possesses either under statutory authority or in pursuance of his ordinary rights as a citizen'. ${ }^{43}$

To see how the law changed in the following years we need to identify two kinds of change, since it is only by understanding the way both have operated together that we can make sense of developments in Post War tort law. The first, and more familiar, change is the emergence of a general duty of care and a general tort of negligence. This, however, was a slow process. Donoghue did not become the leading case it now is overnight. ${ }^{44}$ It was only in the late 196os that it became established in this way. In Dorset Yacht Lord Reid said that though 'the well-known passage' from Lord Atkin's decision 'should not be treated as if it were a statutory definition ... it ought to apply unless there is some justification or valid explanation for its exclusion'. ${ }^{45}$ And in Anns Lord Wilberforce went as far as to say of the majority's opinion in East Suffolk that 'the conception of general duty of care ... had not at the time become fully recognised' ${ }^{46}$ This was a polite way of overruling the majority's opinion in East Suffolk in favour of Lord Atkin's dissent (an opinion not surprisingly thought to have had a better grasp of the principle established in Donoghue). Though important, it must be borne in mind that this development was not confined to liability of public authorities.

The question remains,, however, what was it that led to the broader, general duty, reading of Donoghue. To answer this question we must attend to a second change that was taking place at the same time in judicial attitudes about the relationship between individual and the state. Here, most of the important statements come from extra-judicial writings of some of the leading judges at the time. As early as 1953 Lord Radcliffe explained that this was 'the Century of the Plaintiff, because of ' $[t]$ he widespread use of insurance, so that people have come to feel that there is no loss or mischance that ought not somehow to be made good to the sufferer-by someone else'. And he added, 'so much of industry and public activity is now conducted by large impersonal corporations with large impersonal resources ... [so] it hardly seems even unkind to make them pay for every sort of damage that an individual may have met with at their hands'. In the end he put it to 'humanitarianism', the sense that makes

${ }^{43}$ Ibid, 89. In some of his remarks Lord Atkin was willing to go much further than contemporary or future courts. He suggested that 'something might be said for ... a shopkeeper on [a] route under repair who is for an unreasonably long time deprived of access to his premises for himself and his customers'. Ibid, 91.

${ }^{44}$ In PA Landon, Pollock's Law of Torts (London: Stevens and Sons, 15th ed., 1951) $258 \mathrm{n} 20$ it is stated, for example, that all that Donoghue ... has done is to add a new category of negligence to our law'. See ibid, 257-261, for a disapproving discussion of the case; see also Landon's triumphant note on East Suffolk (1941) 57 LQR 179, which he took to be a return to the 'traditional exposition' (ibid., 181) of negligence, 'shorn of [the] terrors' (ibid., 183) of Donoghue.

${ }^{45}$ Dorset Yacht [1970] AC 1004, 1027.

${ }^{46}$ Anns v Metron London Borough Council [1978] AC 728, 757 (HL). 
people 'indignant' to learn that 'there can be grievances in all the dark and irresponsible record of human affairs which the law is not equipped with a remedy to put right'. ${ }^{47}$

It is important to recognise that this new conception of the relationship between individual and the state was something that judges at the time were fully aware of, and that their refashioning of aspects of tort law, especially negligence, were attempts to make sure the law remains in line with these new developments. The main tool was an increasingly frequent acknowledgement of the significance of 'policy' considerations.$^{48}$ In one particularly clear statement Lord Radcliffe has criticised the English courts for taking the wrong kind of considerations into account when appealing to public policy. What they should consider are not so much on 'what the State or the public requires in its own interest', but rather on 'what the public should guarantee to the individual for the protection of his essential dignity'. ${ }^{49}$

Other statements were even more direct. In Hedley Byrne Lord Pearce said there that the scope of the duty of care will be determined 'upon the courts' assessment of the demands of society for protection from the carelessness of others. ${ }^{5}$ Speaking more generally, Lord Wilberforce, who would go on to deliver the main speech in Anns only a few years later, rejected the view that it is always the 'criminal law, rather than the civil law is [that is] ... the better instrument for conveying social disapproval, or for redressing a wrong to the social fabric.... ${ }^{1}$ Around the same time Lord Denning, who has cast considerable influence on the development of tort law in this period, has written that the 'reason why the law of negligence has been extended so as to embrace nearly all activities in which people engage ... is that, when severe loss is suffered by any one singly, it should be borne, not by him alone, but be spread throughout the community at large'. Even the requirement of fault that was still retained in the law was not explained by appeal to any moral or legal notion of rights, but simply because "compensation without fault would make society bankrupt. ${ }^{52}$

The combined effect of the two developments just described has been, put simply, to introduce a new conception of tort law as one of the means by which the modern welfare state operates. In particular it is interesting to see

${ }^{47}$ Viscount Radcliffe, 'The Place of Law Courts in Society' in Not in Feather Beds, above $\mathrm{n}$ 18, 27, 32-33; see also Nettleship $v$ Weston [1971] 2 QB 691, 699 (CA).

${ }^{48}$ Dorset Yacht Co Ltd v Home Office [1969] 2 QB 412, 426-427 (CA); Lord Reid, 'The Judge as Law Maker' (1972) 12 JPSTL (n.s.) 22, 27; Lord Radcliffe, The Law and Its Compass (London: Faber, 1960) 40-41.

${ }^{49} \mathrm{Ibid}, 57$.

${ }^{50}$ Hedley Byrne and Co Ltd $v$ Heller and Partners Ltd [1964] AC ${ }_{4} 65,536$ (HL), quoted approvingly by Lord Denning MR and Edmund-Davies LJ in Dorset Yacht [1969] 2 QB 412, 426, 433 (CA).

${ }^{51}$ Broome v Cassell \& Co Ltd (No I) [1972] AC 1027, 1114 (HL).

${ }^{52}$ Lord Denning, The Discipline of Law (London: Butterworths, 1979) 280. See also his statement in Dorset Yacht [1969] 2 QB 412, 426 (CA) ("This talk of "duty" or "no duty" is simply a way of limiting the range of liability'). 
how the two developments were used to overcome doctrinal hurdles that stood in the way of developing the law in what was thought to be the desired direction. The wide reading of Donoghue in the context Dorset Yacht and Anns established the idea that as far as the citizen is concerned the state is its 'neighbour' for much of what it does. Typically, Lord Denning was clearest on this front. In Dutton v. Bognor Regis Urban District Council, decided a few years before Anns and dealing with similar issues, he wrote: '[The local council] were entrusted by Parliament with the task of seeing that houses were properly built. They received public funds for the purpose. The very object was to protect purchasers and occupiers of houses. Yet they failed to protect them. Their shoulders are broad enough to bear the loss. ${ }^{53}$ This was the welfare state consensus translated into legal doctrine.

Dutton is important for another, and perhaps more significant, doctrinal innovation. According to familiar negligence doctrine, either one has a duty of care or one does not. As we have seen the majority in East Suffolk has taken the existence of a statutory power to exclude the existence of a duty, thus dooming the claim to fail. Lord Denning overcame this conflicting (and formally binding) case by dismissing as a 'mistake' the distinction drawn there between power and duty. In the context of the welfare state, the logical distinction disappears, or rather a third category, a 'middle term' between the two, becomes operative: what really was pertinent, says Denning, is that the state had 'control' over 'every stage of the work'. ${ }^{54}$ 'Control' is the kind of relation that exists in the relations between employees and employers or between individuals and the state, and it is one that is markedly different from the relation that exists between individuals who are more-or-less equally situated. When the degree of control entrusted to a body is extensive, it is this control that is the basis for the duty of care. With this idea, the distinction drawn in East Suffolk between harms that were the result of risks or harms caused by actions of the defendant and cases in which the risk was created by natural causes could have been rejected, because either way the state had control. When the state was put in charge and has extensive control, it matters little whether the risk was created by the state, for the state was given (or has taken) control for the sake of reducing risks. Having failed to do so, 'its shoulders are broad enough to bear the loss' ${ }^{55}$

Of the two developments just described most academic attention has been directed at the first. Since that development could more easily be accommodated within the 'private' law conception of tort law, it was more easily identified, and whether liked or not, it could have been fit within familiar legal categories. The second development, by contrast, challenged the separation between private law and public law, and hovered close to the

${ }^{53}$ Dutton v Bognor Regis Urban District Council [1972] 1 QB 373, 398 (CA).

${ }^{54}$ Ibid., 391-392. From a purely doctrinal perspective the way Sachs LJ, ibid., at 402-403, avoided East Suffolk by distinguishing it as dealing with omission is no less problematic.

${ }^{55}$ Ibid., 398. 
boundary between law and politics. To many lawyers it was thus perhaps less visible, and undoubtedly less acceptable. Therefore, it is not surprising that some commentators found Anns and the decisions following it difficult to understand. Ignoring the second development that Anns rested on, the decision could be described, improbably, as the result of 'errors in legal analysis ${ }^{156}$ that somehow afflicted a unanimous House of Lords (as well as other appellate courts throughout the Commonwealth). But once the second development is brought into the picture, it is clear why such claims are overly simplistic. Anns was not the result of some oversight, or even a simple case of judges unconsciously following the zeitgeist. What we see, rather, are attempts to change the law to fit what were perceived to be new kinds of relationships between individual and state. As the many statements from the most prominent judges ${ }^{57}$ of the period in pushing the law in this new direction show they clearly recognised that they were changing the law and clearly thought that their actions were necessary for reshaping tort law to better fit the modern welfare state that was at the heart of the post War consensus. And it was this consensus that allowed the courts to bring about such changes without fearing that in doing so they are intruding into the unacceptable domain of politics.

\section{The Thatcher Years}

By the time Margaret Thatcher became Prime Minister there was a growing sense that something has gone wrong: the idea that Britain has become 'ungovernable' has become a truism expressed by many from a wide range of the political spectrum. More and more have subscribed to the view that it was the hitherto sacred cow of the welfare state that was to blame for many of the ills that have befallen British society. By that time the solidarity and trust of the Post-War years were largely depleted, ${ }^{5^{8}}$ and with them also the attraction of public service. Reforms were sometimes mooted, but lack of external pressure or sufficient interest from most prime ministers meant that not much has been done. ${ }^{59}$ All this changed when Thatcher took over. Suddenly external pressure

${ }^{5}$ Robert Stevens, 'Torts' in Louis Blom-Cooper et al (eds), Judicial House of Lords 1876 2009 (Oxford University Press, Oxford 2009) 629, 651. Incidentally, the legal error view has been explicitly rejected in Invercargill City Council v Hamlin [1996] AC 624, 642 (PC (NZ)): In this area 'there is no single right correct answer' but rather different responses based 'at least in part on policy considerations ... [that depend on] community standards and expectations'.

57 The most important judges in this context are Lord Radcliffe, Lord Reid, and Lord Denning. None of them could be described as a leftwing firebrand, and yet they were, to varying degrees willing to openly discuss the creative role of the judge. For a general discussion of their contribution see Robert Stevens, Law and Politics: The House of Lords as a Judicial Body, I8001976 (Chapel Hill: University of North Carolina Press, 1978) 445-59, 468-505.

${ }^{8}$ See Jose Harris, 'Political Ideas and the Debate on State Welfare, 1940-45', in Harold L Smith (ed), War and Social Change: British Society in the Second World War (Manchester: Manchester University Press, 1986) 233, 256-257; Le Grand, above n 32, at 7-11.

${ }^{59}$ Rodeny Lowe, 'Lessons from the Past: The Rise and Fall of the Classic Welfare State in Britain, 1945-76', in Ann Oakley \& A Susan Williams (eds), The Politics of the Welfare State 
from a troubled economy and political will for public service reform were both in abundance and were well received by a society no longer 'servile' in its willingness to accept what were perceived to be poor services. ${ }^{60}$

Just as importantly, Thatcher brought with her an ideology that looked at government and its institutions with mistrust. The welfare state was disliked for tending to divert the most talented people out of wealth-creating business and putting them in business-stifling bureaucracy, and for creating a culture of dependency instead of a culture of responsibility. ${ }^{61}$ The question I explore in this section is whether these shifts had an impact on the judiciary in the area of liability of public authorities, and if they did, what it was.

\section{(a) New Right in the House of Commons: The State Can Only Do Wrong}

Commentators disagree on the degree to which Thatcher (or Thatcherism) is a continuation or departure from conservative ideas. ${ }^{62}$ It is clear, though, that she had little patience for Burkean incrementalism or the retention of institutions that withstood the test of time; nor has she harboured Oakeshottean suspicions of 'rationalist' attempts at political 'science'. Thatcher believed that one could glean from the doctrinaire works of the likes of Friedrich von Hayek or Milton Friedman guiding principles for reform of government and society. If those called for radical changes to, or even the elimination of, old institutions, so be it.

For Thatcher this has meant that the public sector was in need of radical reform. It was a constant source of suspicion and a frequent target of criticism, ${ }^{6}$ which was in line with the ideological dislike of New Right thinkers for state institutions in general and welfare institutions in particular. ${ }^{64}$ These structural changes were grounded in deep ideological shifts in thinking about the relation between the public and private sectors, and more generally between citizen and state. In the former area the changes have resulted in privatisation, deregulation, and in attempt to model the remaining public services on the methods of the

(London: UCL Press, 1994) 37, 48-49; Rodney Lowe, The Welfare State in Britain since 1945 (London: Palgrave Macmillan, 3rd ed., 2005) 98-99.

${ }^{6 \circ}$ Graham Mather, 'Government by Contact', in Frank Vibert (ed.), Britain's Constitutional Future (London: Institute of Economic Affairs, 1991) 73, 75-76.

${ }^{61}$ See, for example, Ralph Harris, Beyond the Welfare State: An Economic, Political and Moral Critique of Indiscriminate State Welfare, and a Review of Alternatives to Dependency (London: Institute of Economic Affairs, 1988) 22-23.

${ }^{62}$ Compare EHH Green, 'The Strange Death of Tory England' (1991) 2 Twentieth Century Brit Hist 67-88, 88 (Thatcher's 'Conservative government ... had very little to do with Conservatism') with D. Willetts, above $\mathrm{n} 36,47$, who emphasises the continuities.

${ }_{3}^{6}$ Andrew Gamble, 'Privatization, Thatcherism, and the British State', (1988) 16 J L \& Soc 1-21, 7; Dennis Kavanagh, Thatcherism and British Politics: The End of Consensus? (Oxford: Oxford University Press, 2nd ed., 1990) 110-111; John Clarke \& Janet Newman, The Managerial State: Power, Politics and Ideology in the Remaking of Social Welfare (London: Sage, 1997) 14-15.

${ }^{6}$ John Clarke, 'Dissolving the Public Realm? The Logics and Limits of Neo-Liberalism' (2004) 33 J Soc Policy 27-48, 30-34. 
private sector. ${ }^{65}$ In the latter, they resulted in attempts to limit the strength and breadth of the social safety net.

At first, this may seem to support expansion of liability of public authorities, for someone holding such a view would tend to reject the idea that the state should be treated any differently from others, which would imply that any immunities enjoyed by public authorities should be abolished. Furthermore, such an approach has been used by some writers to contemplate a rethinking of the relationship between state and individuals along the lines of the relationship between a service provider and customer. Thus, for example, writing in a publication of the Institute of Economic Affairs, the most prominent British New Right think-tank, Graham Mather suggested that public services should be understood in contractual terms, an approach that implies having to pay compensation for 'breach'. ${ }^{66}$

All this might suggest that if anything, Thatcherism would lead to the expansion of liability on the state, but historically this has not been the case, and for reasons that are not difficult to see. Though some arguments may be associated with fear that such liability may lead to an undesired expansion of state institutions, I believe it is moral arguments that provide a more illuminating explanation. The basic idea is has to do with the perceived detrimental impact that imposing liability on the state will have on personal responsibility ${ }^{67}$ Expanding the scope of tort liability on the state effectively turns it into an insurer of last resort, one that potentially covers all possible activities and has no effective limits on the scope of its liability, thus transforming tort law from a regime that deals with the 'private' relations between individuals into one component within the 'public' welfare system. This, according to this view, leads to moral bankruptcy. Thatcher's famous dictum that 'there is no such thing as a society' is often said by her defenders to have been taken out of context. ${ }^{68}$ When brought into context it is clear that she was concerned about a society in which people do not take responsibility for their actions, and are given, by an over-pampering state, disincentives for selfimprovement. It is thus an individualistic call for greater self-reliance and responsibility, and-what is merely the other side of the same coin-the demand that they stop looking to 'blame others for their misfortunes' ${ }^{69}$

The link between welfare and morality makes familiar New Right ideas easy to translate into arguments against the expansion of tort liability of public

${ }^{65}$ On the 'new public management' see Christopher Hood, 'A Public Management for All Seasons?' (1991) 69 Pub Admin 3-19.

${ }_{66}^{6}$ Mather, above n 60, at $73-75,82-84,87-88$.

${ }^{67}$ The link between ideas of self-help and personal responsibility and small government has a long history. See, for example, THE Travers, "Samuel Smiles and the Origins of "Self-Help": Reform and the New Enlightenment', (1977) 9 Albion 161-87, 163, 175-81. For Thatcher's praise for exactly these values see the quote in Robert E Goodin, 'Social Welfare as Collective Social Responsibility', in Social Welfare and Individual Responsibility (1998) 97, 102.

${ }^{68}$ For the full quote see Willetts, above $\mathrm{n} 62$, at $47-48$.

${ }_{9}^{69}$ Atiyah, above n 22, at 138; cf Peter Cane, Atiyah's Accidents, Compensation and the Law (Cambridge: Cambridge University Press, 7 th ed., 2006) 462. 
authorities. If tort law is understood as a system of personal responsibility ${ }^{70}$ then it would be a mistake, both conceptual and moral, to introduce welfare components to it by expanding the liability of public authorities. A basic premise of this view is that a rational, planning, person should take possible future misfortunes into consideration when deciding on future action. On this view it is often the injured person's failure to consider possible mishaps and to protect herself against them (either by investing in safety measures to reduce the risk or by purchasing insurance to reduce the impact of the harm) that is responsible for her misery. ${ }^{71}$ On many occasions it is the 'victim' who will be in a better position, epistemically and morally, than anyone else to consider potential harm that might befall her. In this regard there is nothing to distinguish the risk of harm from, say, an earthquake from the risk of harm brought about by the actions of other people: both are potential setbacks for which one often can, and therefore should, adequately prepare in advance. ${ }^{72}$ Even if the claimant is not similarly situated to prevent an injury from occurring, she will often be in a position to decide for herself whether and to what degree she wishes to deal with its potential impact. In such cases, it is an open question why the defendant should be required to compensate for what the claimant herself was also in a position identify, and therefore to do something about. ${ }^{73}$

A related but somewhat different way of getting to similar conclusions emphasises the importance of choice. 'Choice is the essence of morality', ${ }^{74}$ Thatcher once said, and expansion of tort liability might be thought to remove this choice. The rational, planning, person should be given the choice whether to protect herself against potential risks or whether to run the risk, as well as

70 'Margaret Thatcher was often credited, when she was in office, with defending tort liability as a system of personal responsibility.' PS Atiyah, 'Personal Injuries in the Twenty First Century: Thinking the Unthinkable', in Peter Birks (ed), Wrongs and Remedies $n$ the Twenty-First Century (Oxford: Oxford university Press, 1996) 1, 1.

${ }^{71}$ It is thus interesting to compare Lord Radcliffe words quoted in the text accompanying above $\mathrm{n} 47$, where the availability of insurance was thought an argument for expansion of tort liability, with the position by Lord Hoffmann (whose tort law judgments come closest to endorsing New Right ideology), that the availability of insurance is reason not to impose tort liability. See Stovin v Wise [1996] AC 923, 955, 958 (HL).

${ }_{72}$ See, for example, Richard A Epstein, 'Catastrophic Responses to Catastrophic Risks' (1996) 12 J Risk \& Uncertainty 287-308, 293; Louis Kaplow, 'Transition Policy: A Conceptual Framework' (2003) 13 J Contemporary Legal Issues 161-209, 177; cf JJ Spigelman, 'Negligence: The Last Outpost of the Welfare State' (2002) 76 Australian LJ 432, 433 ('The practical operation of the tort of negligence sometimes give inadequate weight to the conduct of the plaintiff').

${ }^{73}$ Legal economists would draw the line at the point in which it is cheaper for the potential injurer to prevent the harm than it is for the victim. But rights-based libertarian accounts would tend to dismiss or underplay the role cost-benefit analysis in the question of determining individuals' responsibilities to each other. See, e.g., Richard A Epstein, 'A Theory of Strict Liability' (1973) 2 J Legal Stud 151-204, 151-152, passim; Peter W Huber, Liability: The Legal Revolution and Its Consequences (New York: Basic Books, 199o) 6.

${ }^{74}$ Quoted in Bill Jordan, The Common Good: Citizenship, Morality and Self-Interest (Oxford: Blackwell, 1989) $19 \mathrm{n}$ 1. Similar quotes are found in Geoffrey Finlayson, Citizen, State, and Social Welfare in Britain I839-I990 (Oxford: Clarendon Press, 1994) 358-359. 
the choice, if she elects to protect herself against the risk, on how to do so (for example, by changing her level of activity, adopting safety measures, or by getting insurance). By imposing tort liability on an activity the law removes potential victims' ability to choose between engaging in uninsured but cheaper activity and insured but more expensive one, and effectively adds compulsory insurance to the costs of the activity to which all have to pay through their taxes. ${ }^{75}$ In other words, expansion of tort liability both creates moral hazard in providing incentives for people to take less care over themselves and can also operate to remove the choice of those people who wish to take responsibility over themselves.

The question we need to examine now is whether we find these ideas in the decisions limiting tort liability of public authorities in the 1980s. I argue in what follows that we do not.

\section{(b) Old Tories in the House of Lords: The State Can Do No Wrong}

The New Right ideas were by no means unanimously favoured by members of Thatcher's party. Many prominent members of the Conservative party's old guard believed Thatcher's views had little to do with the Tory tradition with which the party had been associated for a long time. Harold Macmillan, by then styled Earl of Stockton, spent the last years of his life bitterly criticising his party's government for getting 'nothing right'. ${ }^{7}$ Another former Conservative prime minister, Edward Heath, was similarly critical of the Thatcher government for losing its way. ${ }^{77}$

My argument will be that the retrenchment of liability in the 1980 os is closer to the views of these critics of Thatcher rather than to hers. At least in the decade in which the change in scope of tort liability began, it is not easy to find court decisions that express the same suspicious attitude towards public authorities; ${ }^{78}$ one can, however, identify in judicial decisions from this period

${ }^{75}$ See, e.g., Huber, above n 73, 207-219.

${ }^{76}$ Stephen Evans, 'The Earl of Stockton's Critique of Thatcherism' (1998) 51 Parliamentary Aff 17,27 . In addition to charting Macmillan's critique, the essay is also useful for summarising younger Conservatives' contrary view that it was Macmillan's policies that were responsible for many of Britain's later troubles. See ibid., 32-34. See also n 36 above; Ivor Crewe \& Donald D Searing, 'Ideological Change in the British Conservative Party', (1988) 82 Am Pol Sci Rev 361-84, 364 .

77 See Finlayson, n 74, 366-367; Stephen Evans, 'Thatcher and the Victorians: A Suitable Case for Comparison?' (1997) 82 History 601-20, 608-610.

${ }_{78}$ Such ideas become more prominent only a decade or more later, especially in the judgments of Lord Hoffmann. See n 71 above; Gorringe, [32] (Lord Hoffmann); Tomlinson $v$ Congleton BC [2003] UKHL 47, [2004] 1 AC 46, [81] (Lord Hobhouse). Lord Hoffmann's influence over his colleagues may be one reason why these ideas persist today. This idea is suggested by Markesinis \& Fedtke, above $\mathrm{n} 23$, but the limitation of the tort liability of public authority started well before he joined the House of Lords in 1995, and as I argue in the text is based on different ideas. 
what have been described as the 'traditional Conservative ideals' of 'strong government, patriotism, and authority'. ${ }^{79}$

To proponents of this approach the state should retain under its control certain inherently 'public' services, not merely by not outsourcing them to private providers, but also by refusing to conceive of these services, and thereby its relation to its citizens, in contractual terms. The 'paternalism' between the state and the individual is the benign concern of the state to those left behind. It is, rather, the relation that exists between subjects and the patria, that is, one that reflects more the 'despotism of parenthood. ${ }^{80}$ This 'Tory culture' emphasised 'deferential attitudes towards authority ... [an] anti-egalitarian ethos and ... status hierarchy'. ${ }^{81}$ Where Burke spoke of the 'generous loyalty to rank and sex, that proud submission, that dignified obedience, that subordination of the heart', ${ }^{82}$ latter-day Tories explained that '[i]t is the absolute duty of the state to have power over its subject ... [and] therefore [the state must] withdraw from every economic arrangement which puts it at the absolute mercy of individual citizens. ${ }^{83}$ This patrician Tory tradition thus rejected both the view that state institutions are dangerous entities whose domain should be curtailed as much as possible and the one that saw citizens as customers who are in a position to make demands from it.

It is almost inevitable that this approach perceives public authorities to be populated by competent, altruistically-motivated, public servants. ${ }^{84}$ And it is this attitude that one finds in the central cases dealing with liability of public authorities from the 1980s. Perhaps the clearest encapsulation is found in Hill v Chief Constable of West Yorkshire, one of the leading case in the trend to limit liability of public authorities. As Lord Keith wrote there:

Potential existence of [tort] liability [of public authorities] may in many instances be in the general public interest, as tending towards the observance of a higher standard of care in the carrying on of various different types of activity. I do not, however, consider that this can be said of police activities. The general sense of public duty which motivates police forces is unlikely to be appreciably reinforced by the imposition of such liability so far as concerns

${ }^{79}$ Crewe \& Searing, above $\mathrm{n} 76,365$.

${ }^{80}$ Roger Scruton, The Meaning of Conservatism (London: Macmillan, 2nd ed., 1984) 110-111: 'postal service[, for example,] is indispensable to the life of the community ... Automatically, therefore, the maintenance of a postal service becomes one of the responsibilities of government.' Nonetheless, '[ $\mathrm{t}]$ he state's relation to the citizen is not, and cannot be, contractual. ... The state has the authority, the responsibility, and the despotism of parenthood'.

${ }^{81}$ See Andrew Gamble, The Free Economy and the Strong State: The Politics of Thatcherism (Basingstoke: Macmillan, 2nd ed., 1994) 170; RW Johnson, The Politics of Recession (London: Macmillan, 1985) 226-227, 234-235, 248.

${ }^{82}$ Edmund Burke, Reflections on the Revolution in France (Harmondsworth: Penguin, 1968 [1790]) 170 .

${ }^{83}$ Scruton, above $\mathrm{n} 8 \mathrm{8}, 111$.

${ }^{84}$ This view is correlative to the old Tory deferential attitude towards state institutions; they both came under attack during Thatcher's years in power. See Sylvia Horton, 'The Public Service Ethos in the British Civil Service: An Historical Institutional Analysis' (2006) 21 Pub Policy \& Admin 32-48, 38-41. 
their function in the investigation and suppression of crime. From time to time they make mistakes in the exercise of that function, but it is not to be doubted that they apply their best endeavours to the performance of it. ${ }^{85}$

Lord Keith was not alone in this view. In Calveley $v$ Chief Constable of Merseyside Lord Bridge expressed a very similar view:

it would plainly be contrary to public policy, in my opinion, to prejudice the fearless and efficient discharge by police officers of their vitally important public duty of investigating crime by requiring them to act under the shadow of a potential action for damages for negligence by the suspect ${ }^{86}$

It is tempting to think that this attitude was confined only to the police, against whom British courts have a long history of timidity. ${ }^{87}$ But the similar statements are found in cases dealing with other public authorities. In another opinion penned by Lord Keith, this time in a Privy Council decision on an appeal from New Zealand, he has written with regard to a claim against a minister, who made administrative decision that was found by the New Zealand courts to have been based on an irrelevant consideration:

in the nature of things, it is likely to be very rare indeed that an error of law of this kind by a minister or other public authority can properly be categorised as negligent. As is well known, anybody, even a judge, can be capable of misconstruing a statute; and such misconstruction, when it occurs, can be severely criticised without attracting the epithet 'negligent.' Obviously, this simple fact points rather to the extreme unlikelihood of a breach of duty being established in these cases.... ${ }^{88}$

Though this discussion looks as though it deals with the question of breach, it appears in the judgment under the heading of 'duty of care' and it leads the court to the conclusion that it would ... be in the public interest that citizens should be confined to their remedy ... in those cases where the minister or public authority has acted in bad faith, ${ }^{89}$ Considerations such as the importance of the rule of law, the importance of subjecting executive action to legal oversight, and the retrospective application of legal interpretation, could all have swayed the decision in a different direction, but in the end it was the same traditional Tort attitude toward state institutions that carried the day. ${ }^{90}$

\footnotetext{
${ }^{85}$ Hill $v$ Chief Constable of West Yorkshire [1989] AC ${ }_{53}, 63$ (HL).

${ }^{86}$ Calveley $v$ Chief Constable of Merseyside [1989] AC 1228, 1238 (HL).

${ }^{87}$ See Robert Stevens, The English Judges: Their Role in the Changing Constitution (Oxford: Hart, rev. ed., 2005) 75 .

${ }^{88}$ Rowling $v$ Takaro Properties Ltd [1988] AC 473, 502 (PC (NZ)).

${ }^{89} \mathrm{Ibid}, 503$.

${ }^{9 \circ}$ One need only look at the decision of the New Zealand Court of Appeal to see a completely different attitude to the relation between citizen and state and hence to liability of public authorities. What is described in the Privy Council as an innocent mistake that does not undermine the sense in which the minister is a committed public servant, is seen in a different light in the New Zealand court's decision that put particular stress on the minister's failure to seek legal advice. Takaro Properties Ltd v Rowling [1986] 1 NZLR 22, 68, 74 (NZ (CA)). Rather than stress the importance of government officials complying with the law the Privy Council's decision stated that 'it is very difficult to identify any particular case in which it can properly be
} 
A final example, this time dealing with a local authority, comes from a somewhat later decision from the Court of Appeal:

One advantage that is claimed for imposing a duty of care is that it encourages people not to be negligent. ... [But] even if psychiatrists and social workers were likely to have to pay damages personally, I do not suppose that they would be any less caring for children in need than they are already; they might, as I have said, adopt defensive practices; but I doubt if their general level of care would change. $^{91}$

This attitude helps explain the widely-discussed 'defensiveness' argument, which alleges that the imposition of liability on public services is likely to lead to a defensive attitude of the public authority, an argument that in fact appears immediately after the passage quoted above from Hill. ${ }^{22}$ The defensiveness argument has been (rightly) criticised by commentators for lack of empirical evidence, and recently, some judges expressed unease about it. ${ }^{93}$ But it makes much more sense on the assumption that public services are populated by officials who are altruistically-motivated and (barring the occasional inevitable mistake) are doing a good job. If this is the case, it follows that any imposition of liability on them will inevitably lead to over-deterrence and to the feared defensive frame of mind. Without such an assumption it is difficult to make any general claim on the likely effect of public services.

In none of the cases discussed above was this line of argument the only one mentioned. Perhaps next to the other arguments, the words quoted above may have looked like empty rhetorical flourishes, what may explain why this particular argument against the imposition of tort liability has received relatively little attention even in books that tried to examine the impact of

said that a minister is under a duty to seek legal advice' Rowling [1988] AC 473, 502. It is worth noting that a decade later a less imperialistic Privy Council conceded that the New Zealand approach reflects a different political attitude, and let a decision affirming Anns and rejecting Murphy stand. See the quote from Invercargill City Council in n 56 above.

${ }^{91} M v$ Newham London Borough Council [1995] 2 AC 633, 675- 676 (CA). See also Brooks $v$ Commissioner of Police of the Metropolis [2005] UKHL 24, [2005] 1 WLR 1495, at [38] ('The fact that no ... legal duty of care exists does not mean ... that a prosecutor or police officer should be anything other than scrupulous in considering the strengths and weaknesses of the case against the defendant. On the contrary, at every stage they will be conscious that, if their decision is wrong, the defendant will be exposed to the risk of suffering substantial harm'); cf Home Office $v$ Harman [1981] QB 534, 557-558 (CA) (a similar view expressed with regard to civil servants generally). A similar attitude is found also in Tony Weir, 'Governmental Liability' [1989] PL 4O63, 46-47: 'In the circumstances, it would be foolish to deplete the meagre resources available [to public authorities] by requiring them to be paid out by way of damages (or contribution) rather than by way of repair and maintenance, especially as it is clear that those at the sharp end really are keen to do a good job with the resources available, though they will doubtless screw up on occasion'.

${ }^{92}$ See also Lord Keith's fear of 'overkill' from the imposition of tort liability in Rowling, at 502, and Murphy, at 472.

${ }^{93}$ See Brooks $v$ Commissioner of Police of the Metropolis [2005] UKHL 24, [2005] 1 WLR 1495 at [3] (Lord Bingham), [6] (Lord Nicholls). In light of this view Lord Bingham tried to refashion the limits of liability of public authorities in Van Colle $v$ Chief Constable of the Hertofordshire Police [2008] UKHL 50, [2008] 3 WLR 593, but remained a lone dissenter. 
ideology on adjudication. ${ }^{94}$ But there is no reason to ignore an argument that appears in many of the central decisions on the subject, especially as essentially the same argument is found in East Suffolk Rivers Catchment Board $v$ Kent, ${ }^{95}$ the case that provided the doctrinal and intellectual foundation for Hill and the cases that followed it. In this case Lord Thankerton says 'there are special circumstances in the case of statutory bodies ... which should lead to the application of a less exacting standard than ordinarily prevails', because in the circumstances in which they operate 'much may be condoned as well-meant error of judgment'. And crucially, these observations are not made specific to the case, but rather are mentioned 'for future guidance. ${ }^{96}$

To highlight the uniqueness of this ideological perspective it is worth comparing it to its two main competitors considered above. First, consider the attitude found in a tort law textbook whose explanations of the law are often informed by New Right ideology:

While we would agree with one commentator that 'fraud, laziness, ineptitude and money-grabbing are the hallmark of Britain's public sector' $\ldots$ it is not clear that finding that a duty of care was owed in this kind of case would bring about any improvement in the dismal performance of public bodies in the UK. ... [E]xpanding the scope of public bodies' liability in negligence only serves to starve them of the money they need to perform their services, as more and more of their funding is diverted into paying for litigation and making compensation payments to claimants. ${ }^{97}$

It is not difficult to see that this view is diametrically opposed to what one finds in the 1980 os cases..$^{98}$ Even more interestingly, the attitude found in the cases is also fundamentally different from the view one finds during the period of political consensus on the welfare state. In Dorset Yacht (of all cases) the imposition of tort liability was challenged by the suggestion that it would lead to an overly defensive attitude. The response of Lord Reid, who as we have seen was one of the architects of the social reformulation of negligence liability, highlights the difference in attitude towards public authorities. After quoting

${ }_{94}$ Most notably Robertson, Judicial Discretion, above n 132, ch. 6; in other areas, though, he has identified a 'pro-administration bias'. Ibid., 339.

${ }^{95}$ East Suffolk Rivers Catchment Board v Kent [1941] AC 74 (HL).

${ }^{96}$ Ibid., 95-96; cf Alexandrou $v$ Oxford [1993] All ER 328, 340 (CA) (making similar statements about the general scope of Hill).

${ }^{97}$ Nicholas J McBride \& Roderick Bagshaw, Tort Law (Harlow: Pearson Longman, 2nd ed., 2005) 203 note 55, quoting Leo McKinstry, 'Idle, Greedy, and Up on a Pedestal: Fraud and Ineptitude Are the Hallmarks of Our Public Sector', Sunday Telegraph (2 May 2004). The passage quoted in the text does not appear in the last edition of the book, although its ideological slant is still very visible. I mention this quote here only to illustrate how very different this view is from what one actually finds in court decisions from the 1980 os.

${ }^{98}$ To see how ideology affects legal outcomes in this area compare the view considered in the text to that of David Howarth. Even though Howarth has a rather similar assessment of some public services, he relies on it for the opposite conclusion: 'council departments notorious for their quasi-professional arrogance will have less of an incentive to respect the rights of those whose lives they affect'. David Howarth, A Textbook on Tort Law (London: Butterworths, 1995) 210; cf AM Linden, 'Tort Law as Ombudsman', (1973) 51 Can Bar Rev 156-68, 161-164. 
from a New York Court of Appeal decision that relied on the defensiveness argument to limit liability on public authorities, Lord Reid famously said:

It may be that public servants in the State of New York are so apprehensive, easily dissuaded from doing their duty, and intent on preserving public funds from costly claims, that they could be influenced in that way. But my experience leads me to believe that Her Majesty's servants are made of sterner stuff. ... I can see no good ground in public policy for giving immunity to a Government Department. ${ }^{99}$

Like the 1980 s cases (and unlike the New Right view) Lord Reid's words show a positive attitude towards public authorities. Where he is different, however, is in coupling this position with a view regarding the changing role of the state, which results in his unwillingness to adopt the deferential attitude towards public authorities which played such a central role in the limitation on liability in subsequent years.

\section{(c) Why Did the Judges Adopt this View?}

That the expansion of the welfare state has gone too far, that something needs to be done to stop Britain's perceived decline, was a view shared by most conservatives in the 1980s, even the 'wets' who did not agree with Thatcher's ideology. ${ }^{100}$ As such the outcomes of the court decisions from this period on tort liability of public authorities would probably have been accepted by many, but the argument developed so far aimed to show that we can identify more specific ideas about the relationship between individuals and the state that explain the decisions. The question that has not yet been answered is why judges in those years have not turned to New Right ideas.

Unlike the identification of the ideological basis of the court's decisions, explaining why they turned this way is obviously more difficult and speculative. I will, however, identify four factors that I believe were at play here. The first is the limited acceptance of Thatcherite ideology even among conservatives and the extent to which Thatcherite ideology may have been the source of clashes between the government and the judges; the second is the correspondence between traditional Tory understanding of the relation between individual and the state and similar attitudes found among members of the judiciary; the third concerns the similarity between old Tory ideology and the prevalent judicial attitudes about the common law; the fourth is that with the of the Post War consensus on the welfare state disappearing, the courts, which were seeking to maintain a non-political stance, could not openly adopt the highly controversial and divisive Thatcherite views; instead, a return to traditional Tory ideas was more easily accepted. Before turning to examine these explanations in more details, I must stress that some of these explanations are more speculative than others, and I cannot tell just how much weight each

99 Dorset Yacht [1970] AC 1004, 1033

100 Andrew Gamble, 'Economic Policy' in Zig Layton-Henry (ed), Conservative Party Politics (London: Macmillan, 1980) 26, 42-43; cf Green, above n 34, 272. 
consideration has had on individual judges. Some may have had a greater inclination towards Tory ideas to begin with and pushed forward a particular change in the law whereas others were just less adventurous and were willing to follow suit in decisions that implied a more minimal role for the courts. Most likely it was some kind of combination of all.

The first point is that when considering the matter substantively, there are many reasons why Tory ideology would be appealing to the judges. I have spoken above about the centrality of authority, a combination of dedication to the maintenance of strong state institutions and a perception of public service borne out of altruistic concern for society, as central to traditional Tory ideology. Similar ideas also something that underlies much judicial thinking. Judges are not civil servants, but they belong to the public sector; and like civil servants they are 'servants of the Crown'. This is not a mere technical formality: as Patrick Devlin conceded the judges are 'at least as concerned as the executive with the preservation of law and order'. ${ }^{101}$ At the same time the status of servants of the Crown can explain the rejection of any sort of quasi-contractual relation between individuals and public service providers: as Lord Steyn put it, '[t]he prime function of the police is the preservation of the Queen's Peace', ${ }^{102}$ not the citizens' rights. To all this one may add a tradition of political constitutionalism, which in part was (and to a great extent still is) reflected judicially in a deferential attitude towards state institutions, ${ }^{103}$ an attitude that may have been in part born out of a political tradition 'unique among modern democracies ... [in] lack[ing] any notion of popular sovereignty'. ${ }^{104}$

The last point focused on the similarity between certain Tory ideas and the ideology of the common law. The third point focuses more on legal practice. There is something about legal practice, perhaps English legal practice in particular, that makes a certain brand of conservatism seem all the more natural for the judge to adopt. What judges often extol as the greatest virtues of the common law method are remarkably similar to what has been described as the intellectual foundations of conservatism: the mistrust of abstract reasoning ('political wisdom is not found in the theoretical speculations of isolated thinkers'); traditionalism in the form of hostility to 'sudden, precipitate and revolutionary change'; and organicism, the view that society is 'unitary, natural

${ }^{101}$ Patrick Devlin, Sunday Times, 6 August 1972 (quoted in Griffith, above n 14, at 293). This is still very much a contemporary issue. See Adam Tomkins, Our Republican Constitution (Oxford: Hart, 2005) 118-124, and compare the similar loyalties of civil servants discussed in Barry J O'Toole, 'T.H. Green and the Ethics of Senior Officials in British Central Government' (1990) 68 Pub Admin 337-52, 348-349.

${ }^{102}$ Brooks $v$ Commissioner of Police of the Metropolis [2005] UKHL 24, 1 WLR 1495, at [30]; Johnson, above n 81, 230-231.

${ }^{103}$ See Stevens, above n 87, 26-28, 63-64; Anthony King, The British Constitution (Oxford: Oxford University Press, 2007) 115-118.

${ }^{104}$ Johnson, above $\mathrm{n} 81,230$. 
growth, an organized living whole not a mechanical aggregate', ${ }^{105}$ a view that may be congenial to the common lawyer both as a description of society, but also (and not coincidentally) as a description of the 'organic growth' of the 'seamless web' of the common law.

It is hard to know whether having such views in the first place is what draws one to the judiciary (or helps one be a successful judge), or whether it is becoming a judge that tends to inculcate such views. ${ }^{106}$ Be that as it may, this approach is often tied to a particular judicial philosophy of restraint. It is notable that even doctrinal commentators have singled out the House of Lords of the 1980 s as excessively 'conservative' at least with regard to its unwillingness to offer innovative solutions to new problems. ${ }^{107}$ This fits perfectly the ideology of non-ideology one finds in many writings of conservatism of this brand. ${ }^{108}$

But this explanation, by itself, is too general and as such cannot account for both the Post-War expansion and the 1980 os retrenchment. As such they can, at best, serve as auxiliaries to other more specific considerations. Two, I think, are significant. The first is that even at the height of Thatcher's power her ideology was never a majority view in the public, perhaps not even among members of her party. It was not the majority view among Conservative MPs and candidates on the eve of her becoming leader of the Conservative Party, ${ }^{109}$ and it was controversial throughout her years as prime minister. ${ }^{110}$ Therefore, if we find that most of the judges were not enamoured of these ideas, this by itself need not be a cause for surprise. But we can say more. Toward the end of Thatcher's premiership her ideology may have been partly responsible for some clashes between the government and the judiciary. Thatcher's New Right circle 'counterpose[d] producers and parasites, the latter including both the old

${ }^{105}$ All quotations come from Anthony Quinton, The Politics of Imperfection: The Religious and Secular Traditions of Conservative Thought in England from Hooker to Oakeshott (London: Faber and Faber, 1978) 16-17.

${ }^{106}$ Patrick Devlin, The Judge (Oxford: Oxford University Press, 1979) 8 ('already at the university where students in the law faculties all over the world are nearly always on the right....'), clearly believes it is the former; Griffith, above n 14, 295, on the other hand seems to favour the opposite view arguing that it is by their 'education and training ... [that British judges] acquired a strikingly homogeneous collection of attitudes' (emphasis omitted).

${ }^{107}$ Ewan McKendrick, 'Restitution of Unlawfully Demanded Tax' [1993] LMCLQ 88-100, 92 ('The last decade in the House of Lords has generally been witnessed by great conservatism and undue deference to Parliament. ... [A] final court of appeal which fails to re-examine rules of law in the light of changed circumstances or fresh arguments is a court which fails to discharge its responsibilities').

${ }^{108}$ Quinton, above $\mathrm{n} 105,16$, calls it 'political scepticism'.

${ }^{109}$ Dennis Kavanagh, 'The Postwar Consensus' (1992) 3 Twentieth Century Brit Hist 1759o, 188-189; Crewe \& Searing, above n 76, 371-372, 378. For the data on the public's attitudes see ibid., 372-378. Paul Whiteley et al., True Blues: The Politics of Conservative Party Membership (Oxford: Clarendon Press, 1994) 58-6o, ch. 6.

${ }^{110}$ Gamble, above n 81, 144-154; Finlayson, above n 74, 366-68. Looking back, it has even been recently suggested that Thatcherism may have been the 'outlier' in the Conservative Party's history. See 'Old Dogs and New Tricks', The Economist (11 February 2010). 
aristocracy and the whole of the public sector ${ }^{111}$ : many senior judges could have been classified as members of both. Moreover, Thatcher was driven by a centralising ambition that sought to establish its ideology by weakening conflicting sources of power: ${ }^{12}$ as a result, along with the bureaucracy and local governments, the judges found themselves at the sharp end of government criticism. This, in turn, has resulted in a more critical attitude toward the government. ${ }^{113}$ Some of this criticism related to questions with a significant legal component to them such as mandatory sentencing, or the incorporation of the European Convention of Human Rights. But at times clashes revolved around the very role of the judiciary: in particular, the judges objected to the government's gestures towards a more 'managerial' approach to the justice system. While for the government this represented attempts at reform similar to those pushed forward in the rest of the public sector, the judges took these as attempts to treat them 'like the grocer's shop at the corner of the street'. ${ }^{114}$ The important point to notice is that such a critical approach towards the government could coexist with continued trust of non-political public services.

The final, and in my view, most important consideration, looks at the doctrinal change in its political context. As mentioned before, for many years after World War II commitment to the welfare state was a mainstream political position. As such support for it was no longer seen as a political view. The courts could have expanded tort liability against the state in the Post War years exactly because the consensus about it among members of the political mainstream made it appear non-ideological. ${ }^{115}$ The welfare state was simply one more fact they had to take into account in shaping the path of the law. The courts could then more easily present the legal innovations they introduced as required by the uncontroversial task of adapting the common law to changing circumstances. But once the consensus on the welfare state evaporated, once the Thatcher's views have become so prominent in the discourse, commitment to the expansion of the welfare state (and with it the continued expansion of tort liability on public authorities) could no longer have been thought of as politically neutral. In the new atmosphere promoting such doctrines would have looked like a concern with 'social justice', a partisan, and hence illegitimate

${ }^{111}$ Ruth Levitas, 'Ideology and the New Right', in Ruth Levitas (ed), The Ideology of the New Right (Cambridge: Polity, 1986) 1, 9; $c f$ Hennessy, above $\mathrm{n} 28,628$, discussing how one of the aims of Thatcher's government was to 'deprivilege' the civil service.

${ }^{112}$ Martin J Smith, 'Reforming the State' in Steven Ludlam \& Martin J. Smith (eds), Contemporary British Conservatism (Basingstoke: Macmillan, 1996) 143, 148-149.

${ }^{113}$ Stevens, above n 87, 49-57; Griffith, above n 14, 327-328.

${ }^{114}$ Quoted in Robert Stevens, The Independence of the Judiciary: The View from the Lord Chancellor's Office (Oxford: Clarendon Press, 1993) 176 (quoting Lord Hailsham, at the time a former Conservative Lord Chancellor); see also Nicholas Browne-Wilkinson, 'The Independence of the Judiciary in the 1980's' [1988] PL 44-57, 48-51.

${ }^{115}$ Contrast this to the judicial attitude to social change when it is not part of the political consensus: Devlin, above n 106, 9 ('I am firmly opposed to ... judicial operations in advance of the consensus'); Lord Justice Balcome, 'Judicial Decisions and Social Attitudes' (1993) 84 Proc Brit Academy 209, 231. 
concern for a judge. ${ }^{116}$ However, for this very reason adopting the New Right's solution to the problem would have been equally unappealing for the judges, for it too could never be seen as part of a consensus. ${ }^{117}$ Turning their back on the Post War developments and resurrecting the majority opinion of East Suffolk was thus the judges' natural response.

With all these considerations taken together we can now see the way in which Thatcher's era may have influenced the judiciary in this area. Though, as I have tried to show, the decisions on public authorities handed down during her tenure do not invoke the sort of arguments one would expect to find from Thatcherite judges, it is nonetheless possible that Thatcherism made those decisions possible. The return to old Tory was a combination of acceptance of some of the political ideas that rose to prominence during the 1980s (such as the widely shared sense among conservatives of all stripes that many of the policies associated with the expanding welfare state have gone too far) together with a return to the old values that, with the collapse of the consensus on the welfare state, may even have come to represent something of a new consensus.

\section{Conclusion}

James Callaghan, Margaret Thatcher's predecessor, famously said: There are times, perhaps once every thirty years, when there is a sea-change in politics. It then does not matter what you say or what you do. There is a shift in what the public wants and what it approves of. I suspect there is now such a sea-change- and it is for Mrs. Thatcher. ${ }^{118}$

When such a shift occurs more than anything else it changes the frame of reference of old debates: some views that until then would have been thought to be beyond the pale become part of the discourse; and if only for some time, other views that had been part of the debate become obsolete. These major shifts are bound to affect judges, even if they assiduously keep away from everyday politics.

Therefore, one need not go as far as to say that legal arguments are mere 'smokescreens' ${ }^{\prime 19}$ for the real considerations driving judicial decision. The considerations found in the decisions clearly have some impact on the judges, even if only for 'external' reasons of wishing to maintain the stability or clarity of the law. But when an ideological sea-change occurs it is likely to sweep the courts with it, and in such instances focusing on the minutiae of doctrine is likely to lead us to miss the bigger picture. In fact, given that deep ideological

${ }^{116}$ Devlin, above $\mathrm{n}$ 106, 8 ('Judges are not concerned with social justice, or rather ... they are not professionally concerned').

${ }^{117}$ Nor did Thatcher ever try to present it as such. As she put it 'consensus seems to be the process of abandoning all beliefs, principles, values, and policies', quoted in Kavannah \& Morris, above $\mathrm{n} 33,2$.

${ }_{118}$ Quoted in Kenneth O Morgan, Callaghan: A Life (Oxford: Oxford University Press, 1997) 697.

${ }^{119}$ Markesinis et al., above n 5, 39 . 
shifts are not always easy to translate into significant changes in the political arena, ${ }^{120}$ there are times in which court decisions-less directly influenced by budgetary limits and the constraints of everyday politics-will be where we will see the effects of these changes more clearly than anywhere else. And even if not every aspect of what we call 'private law' can be explained as reflecting some political ideology, when such sea-changes occur they are going to lead to a reformulation of the foundations of this area of law as well.

The change Callaghan spoke about, while it meant for many a retreat from what was then perceived as the excesses of the 1960 os which led to the woes of the late 1970s, did not necessarily call for the adoption of the radical ideology of the New Right. To many it meant a return to reinvigorated old Tory ideas. For much of this essay I tried to show how the impact of these ideas helps us understand one of the puzzles mentioned in the beginning of this essay, the change that took place in the 1980 s with the law relating to negligence liability of public authorities. But the role these ideas played, and probably still play, in understanding the strict limits imposed on tort liability of public authorities can also help us understand the other puzzle with which I opened this essay, namely the unusually restrictive attitude of English courts in this area of law. Unlike New Right ideas, which have influenced many parts of the Western world during the 1980s, old Tory ideas have been described as 'peculiarly British' and 'almost unintelligible outside these islands. ${ }^{121}$ It is perhaps these peculiar ideas, and their resurgence in the 1980s alongside — and sometimes in opposition to-Thatcherism, that help us understand the peculiarly British attitude to the imposition of negligence liability on public authorities.

${ }^{120}$ See Andrew Gamble, 'The Politics of Thatcherism' (1989) 42 Parliamentary Aff 350-61, especially at 356-61 (arguing that contrary to the significant ideological shift, the political change brought about by Thatcherism was rather modest); Julian Le Grand, 'The State of Welfare' in John Hills (ed.), The State of Welfare: The Welfare State in Britain since 1974 (Oxford: Clarendon, 1990) $338,338-340$ (showing that expenditure as part of the GDP remained roughly the same before Thatcher's rise and during her entire tenure).

${ }^{121}$ James Douglas, 'The Changing Tide-Some Recent Studies of Thatcherism' (1989) 19 Brit J Pol Sci 399-424, 402. See also the quote accompanying note 104. Cf Johnson, above n 81, 234 (in Britain '[ $\mathrm{t}$ ]he national culture is a Tory culture'); Lowe, 'Lessons from the Past', above $\mathrm{n}$ 59, 51 (distinguishing between 'the traditional British view that the role of government is to guarantee certain rights of the "free born Englishman"' and 'the continental "organic" model, in which the government is seen to be an expression of the common interest and therefore not only dispenses rights, but also requires reciprocal responsibilities.'). 